\title{
Németország fejlesztéspolitikája mint a biztonságpolitika eszköze
}

\begin{abstract}
Az ország kül- és biztonságpolitikájához hasonlóan több ponton is ellentmondásos. Az elmúlt évtized során a német fejlesztéspolitika egyre inkább biztonságiasodott, részévé vált a szélesebb biztonságfelfogásnak. Napjainkban Berlin fejlesztéspolitikájának alakitásában több, jelentősen eltérő érdekekkel rendelkező szereplő vesz részt, amelyből fakadóan a német fejlesztéspolitikát a koherencia hiánya jellemzi. A rendelkezésre álló adatokat áttekintve látható, hogy a német hivatalos fejlesztési támogatás legfontosabb célországai Kína, India, Afganisztán, Marokkó, Indonézia voltak, majd 2012-2013-tól már Szíria és Törökország is idesorolhatók. Ezen országok támogatása egyrészt klasszikus fejlesztéspolitikai szempontokat (környezetvédelem, megújuló energiaforrások), másrészt gazdasági érdekeket (hitelnyújtás), harmadrészt (különösen 2015-töl) biztonságpolitikai és migrációs politikai szempontokat követ.
\end{abstract}

Kulcsszavak: Németország, fejlesztéspolitika, segély, humanitárius segély, gazdaság

\section{Speck Gyula: Germany's Development Policy as a Tool of Security Policy}

Similarly to German foreign and security policy, Berlin's international development policy shows ambivalent tendencies. During the last decade, German development policy has been embedded as a tool into the country's broader security policy. Nevertheless, Berlin's development policy can be characterised by incoherence in general, due to the diverging interests of several actors participating in its formation. The biggest recipients of Germany's Official Development Aid are China, India, Afghanistan, Morocco and Indonesia, while Syria and Turkey joined this group only after 2012-2013. The German support towards these countries is based on traditional development policy considerations (environment protection, renewable resources) and economic interests (credit and investment), as well as on its importance from the perspective of security and migration policy (especially after 2015).

Keywords: Germany, development policy, aid, humanitarian aid, economy

\section{Bevezetés}

A Németországi Szövetségi Köztársaság az Amerikai Egyesült Államok után a világ második legnagyobb donorországa, amelynek fejlesztéspolitikája - a német kül- és biztonságpolitika több más területéhez hasonlóan - számos tekintetben ellentmondásos. Az utóbbi években a német médiában és egyes civil szervezetek részéről egyre többször merültek fel olyan kritikák, miszerint a jelenlegi német fejlesztéspolitika a stabil, gazdaságilag erős államokat részesíti előnyben, míg az igazán elmaradott országokat hátra hagyja, mégis 
deklarált célja lenne, hogy kezelje a menekültválságot. ${ }^{1} \mathrm{~A}$ kritikák szerint továbbá a rászoruló országok helyett Németország olyan projekteket és olyan országokat támogat, amelyek már nem a fejlesztéspolitika területéhez tartoznak.

Annak ellenére, hogy Németország az Európai Unió elsőszámú gazdasági hatalma és donorországa, így komoly befolyással bír az Európai Unió fejlesztéspolitikai irányaira is, mégsem született hazai téren átfogó elemzés e témáról. A továbbiakban e hiányosságot kívánjuk pótolni.

\section{A német fejlesztéspolitikai irányok}

Németország esetében a fejlesztéspolitika sokáig alárendelt szerepet töltött be a külpolitikán belül. A fejlesztéspolitika mint a nemzetközi politika része elválaszthatatlan a kül- és biztonságpolitikától, illetve a külgazdaságtól. Német megfogalmazás szerint a fejlesztéspolitika nem fejlesztési segélyekre (Entwicklungshilfe) terjed ki, hanem fejlesztési együttmüködéseket (Entwicklungszusammenarbeit) jelent, vagyis Németország és a partnerországok egymást egyenjogúan kezelve, gazdasági kapcsolatokat építenek ki a fenntartható gazdasági, szociális, ökológiai és társadalmi viszonyok létrehozása érdekében. A fejlesztési együttmüködés egyúttal hozzájárul válságok megelözéséhez, a szegénység elleni harchoz, a jogállamiság, az emberi jogok és a demokrácia támogatásához. ${ }^{2}$

Dirk Messner politológus, a Német Fejlesztéspolitikai Intézet korábbi vezetője a német fejlesztéspolitika történetében három, változó hangsúllyal megjelenő koncepciót különített el: szegénység elleni küzdelem, preventív biztonságpolitika és környezetvédelem. Ezek mellett bár hivatalosan nem kimondottan, de meghatározóak a gazdasági érdekek is. Nyugat-Németország első fejlesztési minisztere, Walter Scheel a hivatalos fejlesztési támogatás legfontosabb funkciójaként az „előbefektetést” határozta meg. Franz Nuscheler, a Duisburg-Esseni Egyetem professzora azonban felhívja arra a figyelmet, hogy a fejlesztéspolitikában nem szabad túlértékelni a gazdasági érdekek érvényesülését, mivel az exportorientált német gazdaság számára nem a fejlesztéspolitika célországai jelentik a legfőbb piacot. ${ }^{3} \mathrm{Ha}$ a fejlesztési partnerek többségét nézzük, ezen állítás igaznak bizonyulhat, azonban mégis árnyalja a képet, hogy Kína Németország meghatározó gazdasági és egyben fejlesztési partnere.

Mindezek mellett említést kell tennünk a biztonsági dimenzióról is, amely meghatározó eleme a német fejlesztéspolitikának. A német fejlesztéspolitikai kezdeményezések a hidegháború alatt a külgazdasági szektor támogatását szolgálták. A biztonságpolitikai szempont hangsúlyosan először az Észak-Dél Bizottság készítette jelentés hatására jelent meg, amely komoly hatást tett az NSZK fejlesztéspolitikájára. A „Brandt-jelentésként”4 elhíresült dokumentum a béke biztosítását a fejlesztéspolitika alapfeladataként fogalmazta meg. Az elkövetkező években az NSZK a fejlesztéspolitikai intézkedéseket a gazdasági ér-

\footnotetext{
Lásd például: Christoph Titz - Maria Feck: Der Wassermann, [online], 2017. 07. 26. Forrás: spiegel.de [2019. 09. 23.] Entwicklungszusammenarbeit, [online], Forrás: bmz.de [2019. 09. 11.]

Franz Nuscheler: Entwicklungspolitik. In: Handbuch zur deutschen Außenpolitik. Siegmar Schmidt - Gunther HeLLMANN - Reinhard Wolf Hrsg., VS Verlag für Sozialwissenschaften, 2007, s. 675-676.

4 Eredeti címe: North South: a programme for survival.
} 
dekeltségek támogatása mellett konfliktusmegelöző eszközként alkalmazta, amely számára előnyös volt, hiszen így katonai erő alkalmazása nélkül gyakorolhatott befolyást a fejlődő országokban. A konfliktusmegelőzés az újraegyesítés után is jelen volt a fejlesztéspolitikában, amely egyre hangsúlyosabban biztonságpolitikai eszközzé is vált. Ezt bizonyítja, hogy a fejlesztési miniszter az elsődlegesen a fegyverexportok engedélyezéséről döntő Szövetségi Biztonsági Tanács állandó tagjává vált. A német szakirodalom szerint 9/11 után a fejlesztéspolitika a biztonságiasodás irányába fordult el. A fejlesztéspolitika részévé vált a szélesebb biztonságfelfogásnak, e megközelítés a 2004. és 2006. évi kormányzati biztonságpolitikai dokumentumokban is visszatükröződik. Heidemarie Wieczorek-Zeul egykori fejlesztési miniszter 2003-ban a fejlesztéspolitikát „költséghatékony” biztonságpolitikának nevezte. A gyakorlatban azonban a civil fejlesztéspolitika összemosódott a biztonság katonai dimenziójával, amely a katonai és civil elemeket ötvöző afganisztáni német tartományi újjáépítő csoportokban, valamint az Afganisztánba irányuló, növekvő hivatalos fejlesztési támogatásban (Official Development Aid, a továbbiakban: ODA) öltött testet. Alexander Brand politológus szerint Németország esetében a fejlesztéspolitika 2000-es években bekövetkezett biztonságiasodása azért történt, mert a fejlesztéspolitika a hidegháború végével veszített jelentőségéből, elismertsége, tekintélye csökkent a többi szakpolitikához képest, a biztonságiasodás pedig kedvező alkalmat nyújtott ennek ellensúlyozására. ${ }^{5}$

\section{A fejlesztéspolitikai intézményrendszer}

A fejlesztéspolitika önállósága többször is megkérdőjeleződött az évtizedek folyamán. Ennek elsődleges oka, hogy a fejlesztéspolitika több mindent foglal magában, mint amire a fejlesztéspolitikáért elsődlegesen felelős Szövetségi Gazdasági Együttmüködési és Fejlesztési Minisztérium (Bundesministerium für wirtschaftliche Zusammenarbeit und Entwicklung, a továbbiakban: BMZ) feladatköre kiterjed. Nuscheler megfogalmazása szerint a fejlesztéspolitika „egy tárcákon átívelő feladat”, vagyis érdekek és szakpolitikai területek komplex összefonódása, amelybe különböző, egymással versengő szereplők vannak bevonva. ${ }^{6}$ Önmagában szembeötlő, hogy Németországban önálló fejlesztési minisztérium müködik, míg más országokban a nemzetközi fejlesztési együttmüködések általában a külügyminisztériumnak vannak alárendelve. ${ }^{7}$ Egyes konkrét külföldi projektek megvalósításában a BMZ-n kívül fontos szerepe van a kereskedelempolitikáért felelős Szövetségi Gazdasági és Energiaügyi Minisztériumnak (Bundesministerium für Wirtschaft und Energie),

\footnotetext{
Alexander BRAND: Sicherheit über alles? Die schleichende Versicherheitlichung deutscher Entwicklungspolitik, Peripherie: Zeitschrift für Politik und Ökonomie in der Dritten Welt, 31. évf. 2011/2, 210., 214-217., 229. o. Forrás: zeitschriftperipherie.de [2019. 09. 21.]

6 Hannes Hermann - Moritz Hillebrecht - Tobias Lehmann: Vom solidarischen Kollektiv, unternehmerischen Entwicklungssubjekten und der Einen Welt. In: Deutsche Außenpolitik. Arenen, Diskurse und Grundlegende Handlungsregeln. Ulrich Roos Hrsg., Springer VS, 2017, s. 179.

A fejlesztéspolitika elsődleges végrehajtói a külügyminisztériumok például Svédországban, Dániában, Finnországban, Hollandiában, Olaszországban, Ausztriában vagy Magyarországon, míg például Spanyolországban és az Egyesült Államokban a fejlesztéspolitikát önálló ügynökségek hajtják végre. Ez a szakpolitika Franciaországban a külügyminisztérium, a gazdasági és pénzügyminisztérium, illetve a Francia Fejlesztési Ügynökség között oszlik meg. Európában jelenleg Németországon kívül egyedül az Egyesült Királyságban működik önálló fejlesztési minisztérium. A donorországok fejlesztéspolitikai intézményi rendszeréről lásd: Development Co-operation Profiles 2019 - official providers, [online], Forrás: oecd.org [2019.09. 11.]
} 
az adósságkezelésért felelős Szövetségi Pénzügyminisztériumnak (Bundesministerium für Finanzen), a humanitárius segélyezésért is felelős Külügyminisztériumnak (Auswärtiges Amt), valamint a Környezeti, Természetvédelmi és Nukleáris Biztonságért felelős Minisztériumnak (Bundesministerium für Umwelt, Naturschutz und nukleare Sicherheit) is. A BMZ-nek tehát nincsen hatásköre több, a szakpolitika szempontjából fontos területen, inkább egy koordinátorszerepet tölt be, amely összefogja a különböző intézményeket és szereplőket, egyetlen, koherens fejlesztéspolitikai gyakorlattá alakítva tevékenységüket. ${ }^{8}$ A fejlesztéspolitika tárcaközi megosztottsága azonban számos kompetenciaütközést vonhat maga után, ahogy erre legutóbb két civil szervezet, a német Welthungerhilfe és a svájci Terre des Hommes közös jelentésükben felhívták a figyelmet. Szerintük rontja a fejlesztéspolitikai koherenciát, hogy Afrika esetében a pénzügyminisztériumnak (Compact with Africa) és a BMZ-nek (Marshallplan mit Afrika) is saját Afrika-fejlesztési stratégiájuk van. ${ }^{9}$

A BMZ nem rendelkezik saját végrehajtási intézményrendszerrel, a fejlesztési projekteket félig állami szervezeteken keresztül hajtja végre. Az államközi bilaterális pénzügyi együttmüködéseket az Újjáépítési Hitelintézetcsoport Fejlesztési Bankján (Kreditanstalt für Wiederaufbau) keresztül, míg a partnerállamok gazdaságfejlesztését, a konfliktus utáni újjáépítést, a klímavédelmi, egészségügyi és oktatási projekteket a 2011-ben több szervezetből összeolvadt Német Nemzetközi Együttmüködési Társaságon (Deutsche Gesellschaft für Intenationale Zusammenarbeit $\mathrm{GmbH}$ ) keresztül hajtja végre. Az Újjáépítési Hitelintézetcsoport részét képező Német Befektetési és Fejlesztési Társaság (Deutsche Investitions- und Entwicklungsgesellschaft) a partnerországok magánvállalkozásait támogatja, a Nemzetközi Migrációért és Fejlesztésért Központ (Centrum für internationale Migration und Entwicklung) a Németországból és az Európai Unióból származó, illetve a Németországban képzett visszatérő szakemberek közvetítését végzi. A Szövetségi Földrajztudományi és Nyersanyag Intézet (Bundesanstalt für Geowissenschaften und Rohstoffe) pedig többek között környezetvédelem-technológiai és nyersanyagmenedzsment-képességek támogatásával vesz részt a BMZ projektjeiben. Ezen társaságok azonban más minisztériumok számára is nyújtanak szolgáltatásokat. ${ }^{10}$

A BMZ költségvetése folyamatosan nőtt az évek folyamán: míg az 1990-es években a szövetségi költségvetés 1,7\%-át tette ki, addig 2018-ban már közel 2,8\%-át. ${ }^{11}$ A 2019-es költségvetési évben 10,2 milliárd euró áll rendelkezésre a minisztérium számára. ${ }^{12} \mathrm{Ez}$ is bizonyítja, hogy a fejlesztéspolitika fokozatosan a német nemzetközi politika meghatározó területévé vált. Ugyanakkor más minisztériumok ODA-hozzájárulásai növekedtek: míg 1995-ben 300 millió eurót tettek ki, addig 2015-ben már 2 milliárd eurót. Különösen a Külügyminisztérium, a Pénzügyminisztérium és a Környezetvédelmi Minisztérium ODA-hozzájárulásai növekedtek. Ezek alapján megállapítható, hogy a fejlesztéspolitika már nem csak a BMZ területe, az évek folyamán a többi minisztérium szerepe is nőtt

\footnotetext{
8 Hermann-Hillebrecht-Lehmann: i. m. 179-180.

9 Daniel Pelz: Hilfsorganisationen stellen deutscher Afrikapolitik schlechtes Zeugnis aus, [online], 2019. 04. 04. Forrás: dw.com [2019. 09. 09]

10 Durchführungsorganisationen, [online], Forrás: bmz.de [2019. 09. 11.]

11 Scope and Structure of German Official Development Assistance: Trends and Implications for the BMZ and Other Ministeries, [online], Deutsches Institut für Entwicklungspolitik, Briefing Paper 16/2018, Forrás: die-gdi.de [2019. 09. 09.]

12 Haushalt, [online], Forrás: bmz.de [2019. 09. 09.]
} 
a globális és regionális kihívások kezelésében. A Német Fejlesztéspolitikai Intézet rámutat e tendencia negatív oldalára is, mivel felmerül a kockázat, hogy a többi minisztérium hivatalos fejlesztési támogatása nem minden esetben szolgálja a Fenntartható Fejlődési Célok (Sustainable Development Goals - SDG) megvalósítását, így az ODA növekedésével több tárcaközi koordinációra lenne szükség a támogatások felhasználásában. ${ }^{13} \mathrm{~A}$ hivatalos fejlesztési támogatások kormányzati és más szervek szerinti megoszlását az 1. ábra szemlélteti.

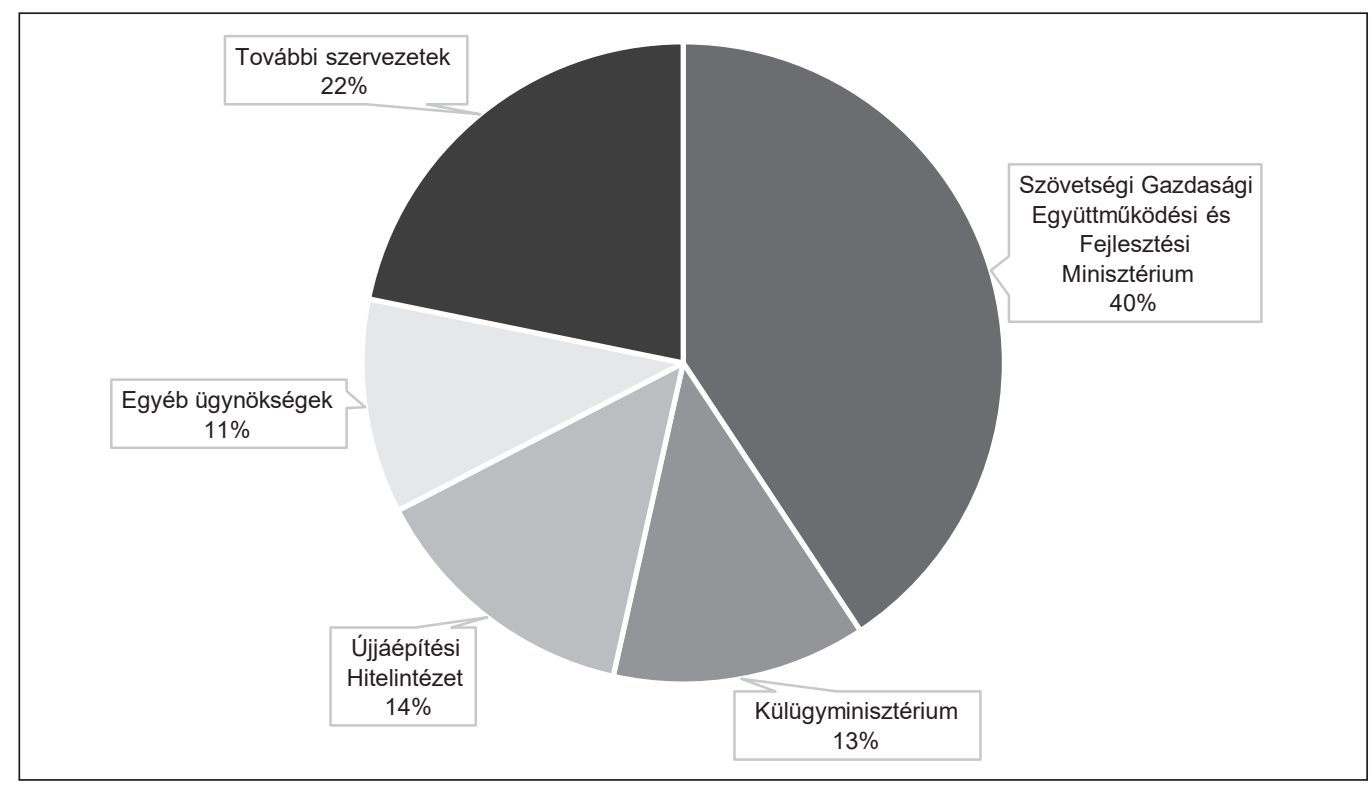

1. ábra: Kormányzati intézmények ODA-hozzájárulásai 2017-ben

Forrás: Development co-operation profiles 2019 - Germany, [online], Forrás: oecd-library.org [2019. 09. 09.]

\section{A fejlesztéspolitika a stratégiai dokumentumokban}

Németország kiemelten kezeli az Agenda 2030 és a Fenntartható Fejlődési Célok megvalósítását, amelyért globális felelősséget vállal. Ennek megfelelően a jelenlegi kormány a fejlesztéspolitikát a Fenntartható Fejlődési Célok kulcsfontosságú eszközének tekinti. A szövetségi kormány az Agenda 2030 elfogadása után 2016-ban megalkotta a Fenntarthatósági Stratégiát a 17 Fenntartható Fejlődési Cél megvalósítása érdekében. E stratégia követi az Agenda 2030 „leaving no one behind” („,senkit nem hagyunk hátra”) koncepciót, vagyis, hogy az SDG minden népcsoporthoz elérjen, legföképp azokhoz, amelyek különösen elmaradottak, tehát nem szabad különbséget tenni azok között, akik saját erőből is képesek a fejlesztési célokat megvalósítani, és akik nem. A BMZ feladata, hogy végrehajtsa

13 Scope and Structure of German Official Development Assistance: Trends and Implications for the BMZ and Other Ministeries: i. $m$. 
e stratégiát, szoros együttmüködésben a civil és gazdasági szereplőkkel. ${ }^{14}$ A BMZ 15. 2017-ben megjelent jelentése a fejlesztéspolitikát a szövetségi kormány globális kihívásokat kezelő politikájaként határozza meg, így e politikának együtt kell működnie a szakterület többi szereplőivel is. ${ }^{15}$

A szövetségi kormány jelenlegi fejlesztéspolitikáját a BMZ 2018. októberben megjelent „Entwicklungspolitik 2030” címü stratégiai dokumentum foglalja össze. A dokumentum értelmében a fejlesztéspolitikának a jövőben öt nagy globális kihívással kell szembenéznie: 1. demográfiai változások; 2 . az erőforrások szűkössége; 3 . klímaváltozás; 4. digitalizáció; 5. migráció. A dokumentum leszögezi, hogy bár a világ 2015-ben fontos eredményeket ért el a Fenntartható Fejlődési Célok és Az éghajlatváltozásról szóló Párizsi Megállapodás elfogadásával, a siker érdekében gyakorlati cselekvésre van szükség. ${ }^{16}$

A stratégia mindennek érdekében 6 eszközt határoz meg: 1. a német ODA-nak meg kell közelítenie a GNI 0,7\%-át; 2. a partnerországokban szorgalmazni kell a magánbefektetéseket, a világkereskedelmi rendszert fenntarthatóvá és igazságosabbá kell tenni különösen Afrika fejlődése érdekében; 3 . a fejlesztési együttmüködés partnerországainak a fejlesztési célok érdekében növelniük kell saját hozzájárulásukat, tiszteletben kell tartaniuk az emberi jogokat és a jogállami struktúrákat, és harcolniuk kell a korrupció ellen; 4. a partnerországok kapcsán a stratégia leszögezi, hogy Németországnak csökkentenie kell a partnerországok számát, a fejlesztési együttmüködést még több feltételhez kell kötni; 5. további fejlesztéspolitikai eszközként határozza meg a politikai alapítványokkal és más nem állami szereplőkkel való együttműködési hálózat létrehozását; 6. erősíteni kell az ENSZ szakosított intézményeivel (UNICEF, UNDP, UNHCR, Világbank) történő multilaterális együttmüködést.

A dokumentum külön foglalkozik a válságövezetekben használatos fejlesztési eszközökkel. Aktuális kiemelt régiókként Szíriát, Jement és Bangladest nevesíti, emellett kiemeli, hogy Szíriában Németország a legnagyobb donorország, a szíriai menekültek ellátásában támogatja Jordániát, Irakot, Libanont és Törökországot, többek között iskolák, egészségügyi létesítmények (újjá)építésével. A menekültek, lakhelyükről elüldözött vagy a Németországból visszatérő, illetve a helyben maradt személyek életkörülményeit hivatott javítani az Otthon Perspektíva (Perspektive Heimat) kezdeményezés különféle programokon keresztül (például fiatalkorúak foglalkoztatása, szakmunkásképzés, pénzügyi szolgáltatások elérése, munkahelyek létrehozása stb.) Az említett személyek közvetítésére és kvalifikálására a BMZ tanácsadó központokat létesít a Nyugat-Balkánon (Albánia, Koszovó, Szerbia), Észak- és Nyugat-Afrikában (Ghána, Marokkó, Szenegál, Tunézia, Nigéria) és Irakban. ${ }^{17}$

14 Deutsche Nachhaltigkeitsstrategie. Neuauflage 2016, [online], 2016, Forrás: bundesregierung.de [2019. 09. 09.] 23. o.; Entwicklungspolitik ist Zukunftspolitik. Ressortbericht zur Umsetzung der Deutschen Nachhaltigkeitsstrategie und der SDGs, [online], 2018, 2-3. o. Forrás: bmz.de [2019. 09. 09.]

15 Entwicklungspolitik als Zukunfts- und Friedenspolitik. 15. Entwicklungspolitischer Bericht der Bundesregierung, [online], 2017, 1., 24. o. Forrás: bmz.de [2019. 09. 09.]

16 Entwicklungspolitik 2030. Neue Herausforderungen - neue Antworten, [online], 2018, 2-5. o. Forrás: bmz.de [2019. 09. 11.]

17 Entwicklungspolitik 2030. Neue Herausforderungen - neue Antworten: i. m. 7-10. 
A BMZ fontos eszköznek tekinti az afrikai kontinens fejlesztésére 2017-ben elindított „Afrikai Marshall-tervet” (Marshallplan mit Afrika). A terv az Afrikai Unió Agenda 2063 tervével összhangban elérendő célokat határoz meg és ajánlásokat fogalmaz meg az élelmezésre és mezőgazdaságra, a természetes életfeltételek biztosítására, az energiára és infrastruktúrára, valamint az egészségre, képzésre és társadalmi biztonságra vonatkozóan, továbbá kiemelt „reformpartnerségeket” folytat Elefántcsontparttal, Ghánával és Tunéziával. ${ }^{18}$ Az afrikai Marshall-terv három oszlopra épül: 1. gazdaság, kereskedelem és foglalkoztatás; 2. béke, biztonság és stabilitás (többek között a menekülést kiváltó okok megszüntetésére); 3. demokrácia, jogállamiság, emberi jogok. ${ }^{19}$

A fejlesztéspolitika jelenleg is fontos szerepet játszik a szövetségi kormány biztonságpolitikájában. A 2017-ben kiadott válságmegelőzési és konfliktuskezelési irányelvek ${ }^{20}$ szerint a békéhez szükség van a kül-, biztonság- és fejlesztéspolitika együtthatójára, ahogy e szakpolitikák a fenntartható béke „vízióját” követik, összhangban az Agenda 2030 célkitűzéseivel. A BMZ 15. fejlesztéspolitikai jelentésének címe is ezt sugallja („Entwicklungspolitik als Zukunfts- und Friedenspolitik” vagyis az „A fejlesztéspolitika, mint jövő- és békepolitika”). Az említett irányelvek értelmében a kormány kötelezi magát, hogy a szaktárcák intézkedései illeszkedjenek az Agenda 2030 megvalósításához. ${ }^{21}$ A 2016-ban kiadott Fehér könyv hasonló kontextusban hangsúlyozza a fejlesztéspolitika szerepét. ${ }^{22}$

\section{Németország fejlesztéspolitikájának eredményei}

Németország a második legtöbb hivatalos fejlesztési támogatást biztosító ország a világon (lásd a 2. ábrát). Az OECD előzetes adatai alapján 2018-ban 25 milliárd dollár nettó összegü hivatalos fejlesztési támogatást nyújtott, amely bruttó nemzeti termékének 0,61\%-a, így tehát jelenleg nem teljesíti az uniós tagállamok által 2005-ben kitüzött 0,7\%-os ODA-részarányt. A német ODA-hozzájárulás 2015 és 2018 között jelentősen, 6,9 milliárd dollárral nőtt, így Németország történetében először érte el a GNI 0,7\%-át 2016-ban, köszönhetően elsősorban a menekültekre fordított támogatás emelkedésének (lásd a 3. ábrát). ${ }^{23}$

18 A BMZ stratégiája szerint a további partnerországok felvételét fogják megvizsgálni korrupciós, jogállamisági és emberi jogi kritériumok alapján.; Uo. 11.

19 Afrika und Europa - Neue Partnerschaft für Entwicklung, Frieden und Zukunft, [online], 2017. Forrás: bmz.de [2019. 09. 22.]

20 A dokumentum címe: „Krisen verhindern, Konflikte bewältigen, Frieden fördern. Leitlinien der Bundesregierung”.

${ }^{21}$ Krisen verhindern, Konflikte bewältigen, Frieden fördern. Leitlinien der Bundesregierung, [online], 2017, $14 ., 41 ., 45$. , 127., 150. o. Forrás: auswaertiges-amt.de [2019. 09. 09.]

22 Weißbuch 2016 zur Sicherheitspolitik und zur Zukunft der Bundeswehr, [online], 2016, 57. o. Forrás: bundesregierung. de [2019. 09. 09.]

23 Development co-operation profiles 2019 - Germany: i. m.; A Gazdasági Fejlesztési és Együttműködési Szervezet Fejlesztési Támogatási Bizottsága 2017-ben határozta meg, mely tételek számolhatók el hivatalos fejlesztési támogatásként: a donorországba érkező menekültek támogatásába csak olyan tételek számítanak bele, mint élelmiszersegély, oktatás, menedéknyújtás, de az integráció már nem. Az ilyen fajta támogatás csak 12 hónapig számolható el hivatalos fejlesztési támogatásként. Lásd: In-donor refugee costs in ODA, [online], Forrás: oecd.org [2019. 09. 23.] 


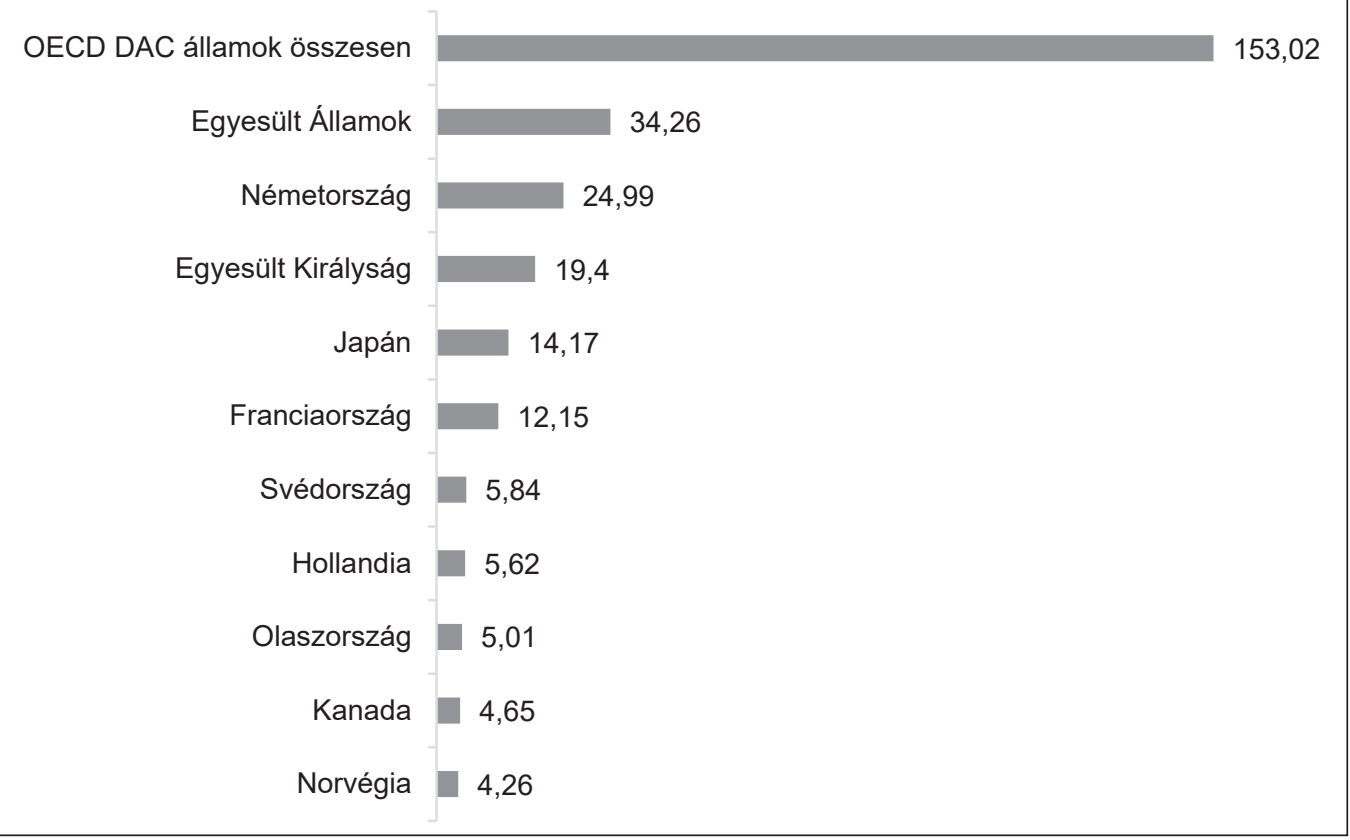

2. ábra: A top 10 OECD DAC ország hivatalos fejlesztési támogatása 2018-ban (milliárd dollárban)

Forrás: Geber im Vergleich 2018, [online], Forrás: bmz.de [2019. 09. 09.]

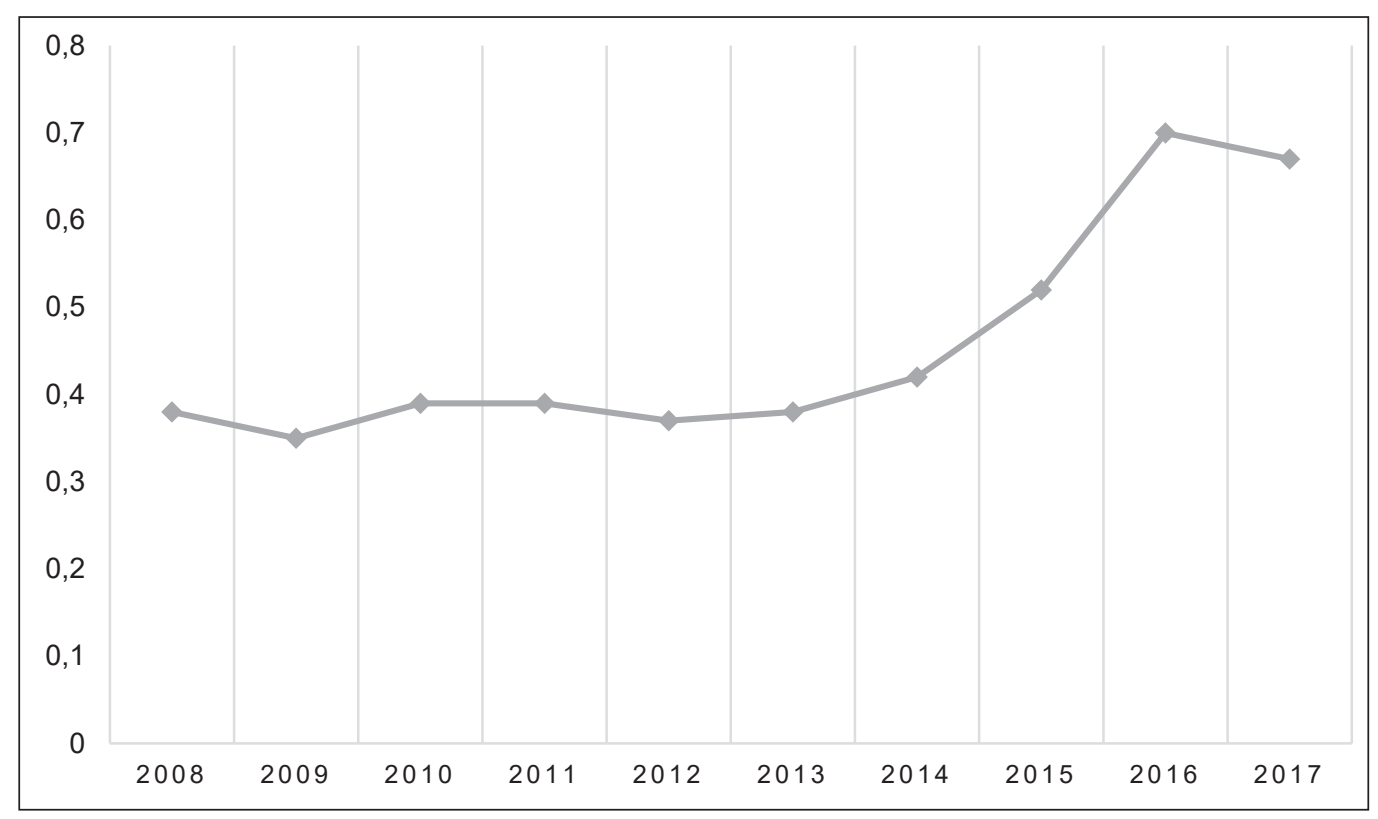

3. ábra: Hivatalos fejlesztési támogatás a bruttó nemzeti jövedelem arányában

Forrás: Development co-operation profiles 2019 - Germany: i. $m$. 
2017-ben Németország teljes hivatalos fejlesztési támogatásának 81,4\%-át bilaterális alapon nyújtotta, 18,6\%-át pedig nemzetközi szervezeteken, elsősorban az ENSZ-en és az Európai Unión keresztül. ${ }^{24}$ Fontos megjegyezni, hogy az Európai Unió Fejlesztési Alapjának legnagyobb finanszírozója 2018-ban Németország volt, az alap 20,58\%-át adta. ${ }^{25}$

A kiadásokat tekintve a bilaterális ODA ugyanezen évben 37,1\% volt „programozható támogatás” ${ }^{26}$ míg tekintélyes részt tett ki a Németországba érkező „menekültek támogatása” is (az ODA 26,7\%-a). A legfontosabb ODA-folyósítási csatorna 2017-ben az állami szektor volt (2017-ben a bruttó bilaterális ODA 67,9\%-át tette ki), míg a bruttó bilaterális ODA kisebb részét a magánszektor $(2 \%)$, nem-kormányzati szervek $(6,6 \%)$, illetve egyetemek és kutatóintézetek (6,5\%) juttatták. ${ }^{27}$ A támogatások tekintélyes része a szociális infrastruktúra és szolgáltatások fejlesztésére irányult (2017-ben a bilaterális ODA 29,4\%-a, 7,7 millió dollár), ezen belül is a kormányzás és a civil társadalom erősítésére, valamint az oktatásra. Kiemelendő még az energiaszektor és a humanitárius segítségnyújtás (2017-ben az ODA 9\%-a és 11\%-a). A bilaterálisan nyújtott bruttó ODA 47,2\%-a támogatta a környezetvédelmet, ezzel bőven az OECD DAC ${ }^{28}$ tagállamok 33\%-os átlaga felett teljesítve. ${ }^{29}$

Németország humanitárius segélyezési tevékenységéről elmondható, hogy 2014 óta megnégyszereződött az e célra fordított forrás, így Németország a világ második legnagyobb humanitárius segélynyújtója. A segélyek azonban földrajzilag aránytalanul oszlanak meg: 2015-ben Németország segélyeinek 60\%-át juttatta a közel-keleti térségbe (ezen belül 40\%-ot Szíriába és a szomszédos országokba), míg a világon a segélyre szorulók csak 25\%-a él a Közel-Keleten, ugyanakkor 2017-ben egyáltalán nem biztosított segélyt a három legsúlyosabb humanitárius katasztrófa kezelésére Szenegálban, Kubában és Dzsibutiban. ${ }^{30}$

A német fejlesztéspolitika teljesítményéről több értékelést is figyelembe vehetünk. Az OECD DAC 2018-as évközi vizsgálata megállapította, hogy Németország különösen hangsúlyt helyez a klímaváltozás kockázataira, a megújuló energiaforrásokra, továbbá aktívan támogatja az erős felemelkedő gazdaságokat és a globális kereskedelmi javak áramlását. $^{31}$

24 Development co-operation profiles 2019 - Germany: $i . m$.

25 Annual Accounts of the European Development Fund 2018, [online], 2019. 06. 26., 31. o. Forrás: europarl.europa.eu [2019. 09. 21.]

26 Az OECD programozható támogatás alatt az olyan segélyeket érti, amelyeket a donorok célzottan egyes országok vagy régiók számára alakítanak ki és amelyekbe komoly beleszólása van a partnerországoknak is. Lásd: Country programmable aid (CPA), [online] Forrás: oecd.org [2019. 09. 11.]

27 Development co-operation profiles 2019 - Germany: i. $m$.

28 A Gazdasági Együttmüködési és Fejlesztési Szervezet Fejlesztési Támogatási Bizottsága (Organisation for Cooperation and Development, Development Assistance Committee).

29 Development co-operation profiles 2019 - Germany: i. $m$.

30 Ralf SüDhoff - Sonja Hövelmann: Where does German humanitarian assistance stand? [online], 2019. 03. 08., 2-3., 5. o. Forrás: chaberlin.org [2019. 09. 20.]

31 Germany Mid-term Review, 7 November 2018, Berlin, [online], 2018. 12. 14. Forrás: oecd.org [2019. 09. 10.] 
A 2018-as Commitment to Development Index ${ }^{32}$ értékelése szerint a világ 27 leggazdagabb országa között Németország Finnországgal együtt a harmadik legelkötelezettebb ország a fejlesztési tevékenységét tekintve, ezzel a legmagasabb helyezést elérve a G7-országok között. Az index szerint Németország fejlesztéspolitikája jól teljesít a kereskedelmi szektorban (például javítja a befektetési lehetőségeket, ösztönzi a nemzetközi áruforgalmat) és a migrációs szektorban (erős a menekültekkel szembeni befogadókészsége, részese valamennyi migrációs egyezménynek), azonban a biztonsági szektorban (hozzájárulás a békefenntartáshoz, a nem demokratikus országokba irányuló fegyverexportok csökkentése) és a segélyezési szektorban (segélyezés minőségének javítása a programok közötti átfedések csökkentésével, a koordináció erősítésével) kellene leginkább fejlődnie. ${ }^{33}$ A Németországba érkező menekültekre fordított forrásokkal kapcsolatban a korábban említett Welthungerhilfe és a Terre des Hommes civil szervezetek hibás iránynak tartják, hogy a szövetségi kormány összekeveri a belpolitikát a fejlesztéspolitikával, mivel 2018-ban a fejlesztési források negyedét (22,18 milliárd eurót) németországi menekültekre fordította. ${ }^{34}$ Ennek kapcsán a Német Fejlesztési Intézet felhívta a figyelmet, hogy egyfelöl a Németországba érkező menekültekre fordított kiadásoknak nincs fejlesztési funkciójuk, nem irányulnak valamely fejlődő országba, másrészt a menekültek beáramlásának csökkenésével a német hivatalos fejlesztési támogatás is csökkeni fog, így megint nem fogja elérni a bruttó nemzeti termék 0,7\%-át. ${ }^{35}$

\section{Partnerországok és fókuszpontok}

A német fejlesztéspolitika közelebbi vizsgálata céljából érdemes szemügyre venni a célországokat, mivel a fejlesztési források eloszlásának vizsgálata indikátora lehet Németország nemzetközi politikára gyakorolt befolyásának. A BMZ fejlesztéspolitikai koncepciótól függetlenül mindig is előnyben részesített bizonyos országokat, úgynevezett „globális partnereket”. Jelenleg a német fejlesztéspolitika bilaterálisan 50 országgal működik együtt különböző országprogramok keretében, ezen belül bizonyos országokkal tematikus és regionális programok keretében támogatja az együttmüködést, például klímaváltozás elleni harcban vagy válságmegelőzésben. A BMZ szerint a partnereket a fejlesztéspolitikai szükségesség (a partnerország gazdasági, környezeti, társadalmi, politikai és ökológiai helyzetét, valamint a szegénység mértékét figyelembe véve), a partnerország fejlesztési orientáltsága (demokratikus fejlődés, jogállamiság, emberi jogok védelme), a német nemzeti érdekek

\footnotetext{
32 A Center for Global Development által készített Commitment to Development Index a világ 27 leggazdagabb országa fejlesztési tevékenységének minőségét méri a donorországok méretéhez és gazdasági erejéhez viszonyítva. Az index hét fejlesztési területet vizsgál több száz hatékonysági indikátor alapján: segély (mennyiség és minőség), kereskedelem, pénzügy, migráció, környezetvédelem, biztonság és technológia. Az index nem csak a fejlesztések eredményét (például, hogy a fogadó országban mennyire sikerült csökkenteni az üvegházhatású gázok kibocsátását), hanem szándékát is mérik (például mennyi időbe telt az üvegházhatású gázok kibocsátásának lecsökkentése a fogadó országban). Az indexről bővebben lásd: The Commitment to Development Index: 2018 Edition. Methodological Overview Paper, [online], 2018. Forrás: cgdev.org [2019. 09. 12.]

33 Commitment to Development Index 2018 Germany, [online], Forrás: cgdev.org [2019. 09. 20.]

34 Bericht: Deutsche Entwicklungspolitik missachtet die Ärmsten, [online], 2019. 04. 04. Forrás: dw.com [2019. 09. 21.]

35 Scope and Structure of German Official Development Assistance: Trends and Implications for the BMZ and Other Ministries: i. m.
} 
és az Agenda 2030 végrehajtása szempontjából választják ki. ${ }^{36} \mathrm{~A}$ fejlesztési minisztérium 2015-ös stratégiai dokumentuma ezenfelül kiemel hat, úgynevezett globális fejlesztési partnert: Brazíliát, Indiát, Indonéziát, Kínát, Mexikót és Dél-Afrikát. Ezen országok jelentős fejlődésen mentek keresztül az elmúlt években, gazdasági és politikai hatalmi centrumokká váltak, ennélfogva Németország bi- és multilaterális keretek között kíván együttmüködni velük a fejlesztési és fenntarthatósági célok elérésében. Ehhez Németország támogatást nyújt, de a partnereknek saját maguknak is felelösséget kell vállalniuk. ${ }^{37}$

A hivatalos fejlesztési támogatás elsődleges célpontjai ázsiai és afrikai országok voltak, 2016 és 2017 között mindkét térségben növekedett a támogatás. 2017-ben a bruttó hivatalos fejlesztési támogatás 26\%-a irányult a 10 legtöbb támogatást fogadó országba. ${ }^{38}$ Ezek döntő többsége a Világbank meghatározása ${ }^{39}$ szerint közepes jövedelmü ország volt: öt felsőközép jövedelmű (Kína, Törökország, Irak, Jordánia és Mexikó), három alacsony-közép jövedelmű (India, Marokkó és Indonézia), a maradék kettő (Szíria és Afganisztán) pedig alacsony jövedelmü (lásd a 4 . ábrát).

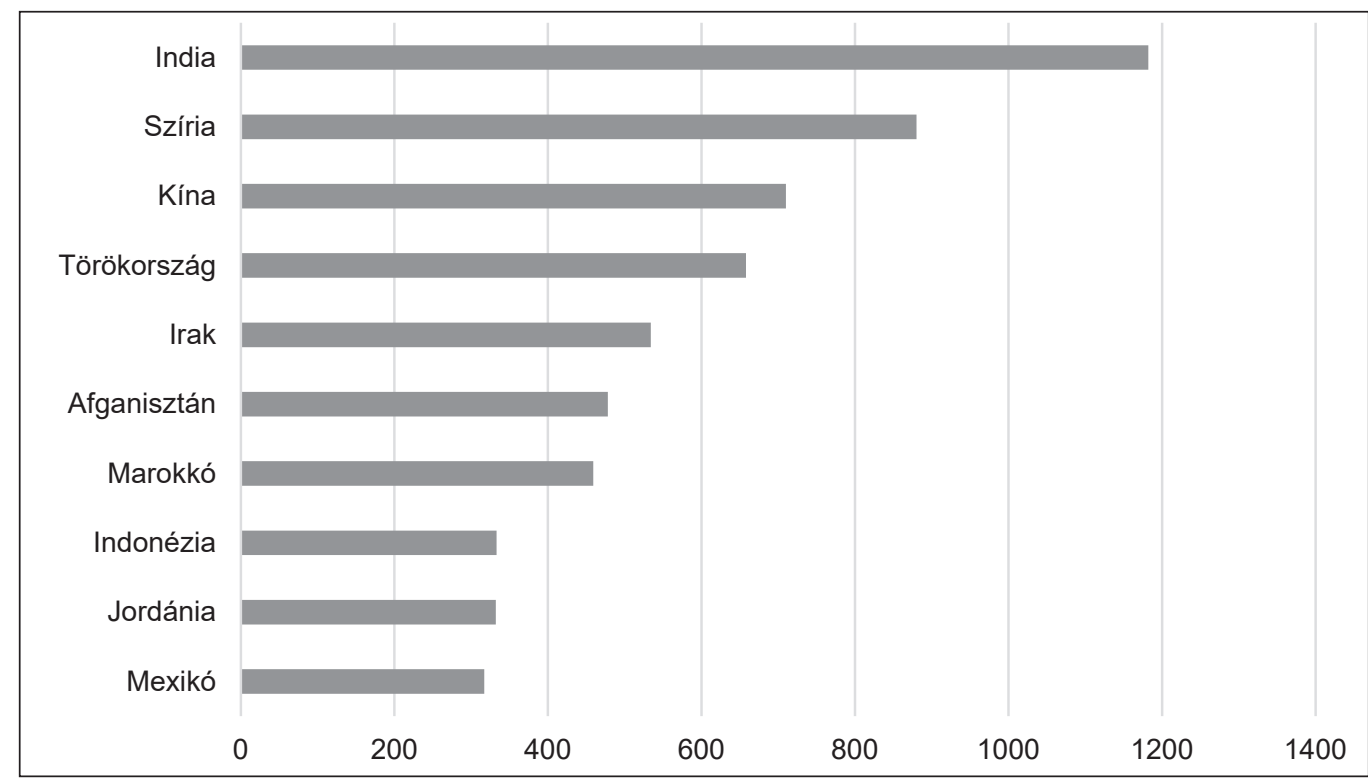

4. ábra: A német hivatalos fejlesztési támogatás top 10 célországa 2017-ben (a támogatás mértéke millió dollárban)

Forrás: Development co-operation profiles 2019 - Germany: i. $m$.

36 Auswahl der Kooperationsländer, [online], Forrás: bmz.de [2019. 09. 21.]

37 Entwicklungspolitische Zusammenarbeit mit Globalen Entwicklungspartnern, [online], 2015, 5-7. o. Forrás: bmz.de [2019. 09. 23.]

38 Development co-operation profiles 2019 - Germany: i. $m$.

39 A Világbank jelenleg négy jövedelmi kategóriába sorolja az országokat: alacsony, alacsony-közép, felsőközép és magas. A jövedelmet amerikai dollárban, egy före eső bruttó nemzeti jövedelemben méri. Ezen kategóriákat alkalmazza az OECD is. A kategóriákat lásd: World Bank Country and Lending Groups, [online], Forrás: databank.worldbank.org [2019. 09. 09.]; a magyarázatról: How does the World Bank classify countries?, [online], Forrás: datahelpdesk.worldbank.org [2019.09.09.] 
2017-ben a legkevésbé fejlett országokba irányuló német hivatalos fejlesztési támogatás a GNI 0,11\%-át tette ki, így azonban elmaradt az ENSZ által meghatározott 0,15-0,20\%-tól. A fenti arányok az elmúlt 10 évben is hasonlóan alakultak, a legkevésbé fejlett országok 2012-ben kapták a legtöbb támogatást, a német hivatalos fejlesztési támogatás 23\%-át. ${ }^{40}$ Némiképp árnyalja a képet, hogy a BMZ 2019. áprilisi tájékoztatása szerint 2017-ben és 2018-ban a 20 legmagasabb hozzájárulás 7 legkevésbé fejlett országba irányult (Afganisztán, Etiópia, Burkina Faso, Mali, Niger, Ruanda és Uganda). ${ }^{41}$

Az elmúlt több mint 10 évet áttekintve látható, hogy a német hivatalos fejlesztési támogatás legfontosabb célországai Kína, India, Afganisztán, Marokkó, Indonézia voltak, majd 2012-2013-tól már Szíria és Törökország is idesorolhatók. ${ }^{42}$ Ezen országok támogatása egyrészt klasszikus fejlesztéspolitikai szempontokat (környezetvédelem, megújuló energiaforrások), másrészt gazdasági érdekeket (hitelnyújtás), harmadrészt (különösen 2015-től) biztonságpolitikai és migrációs politikai szempontokat követ. Elsőként a globális fejlesztési partnereket vesszük sorra.

Kína 2018-ban már harmadik éve Németország legfontosabb kereskedelmi partnere a kereskedelmi volument tekintve, megelőzve Hollandiát és az Egyesült Államokat, továbbá a fejlesztéspolitikában is globális partnernek számít. ${ }^{43}$ Gerd Müller miniszter ${ }^{44}$ szerint a Kínával való fejlesztési együttműködés főleg az Újjáépítési Hitelintézet hiteleit jelenti, amelyeket Kína kamatostul fog visszafizetni, a klasszikus fejlesztési együttmüködést Németország már évekkel korábban beszüntette. ${ }^{45} \mathrm{~A}$ hitelek többek között német vállalatok befektetéseit támogatják elsősorban megújuló energiaforrások kiépítésében, továbbá támogatják a hulladékmentesítést, újraerdősítést, egészségügyi modernizációt vagy HIV/ AIDS-prevenciót ${ }^{46}$ E projektek Kína érdekeit is egyértelműen szolgálják, mivel Hszi Csinping elnök víziója, hogy Kína „ökológiai civilizációvá” váljon, továbbá a jelenlegi ötéves tervben is szerepel, hogy Kína fenntartható, minőségi növekedést kíván produkálni. ${ }^{47}$ A miniszter szerint a Kínával való együttmüködés fontos szerepet tölt be a Fenntartható Fejlődési Célok elérésében az afrikai kontinensen is, így bizonyos afrikai projekteket (például egy függőhíd megépítését Mozambik fővárosában) közösen tudnak megvalósítani. ${ }^{48}$

Németország India legfontosabb kereskedelmi partnere az Európai Unión belül, globális viszonylatban pedig a hatodik legfontosabb partner. Globális partnerként kulcsszerepe van a globális fejlesztési kérdésekben, valamint a nemzetközi tárgyalásokon (G20, Dohaforduló, klímaegyezmények stb.). ${ }^{49} \mathrm{Az}$ Indiával való együttmüködés lefedi a megújuló

40 Development co-operation profiles 2019 - Germany: i. $m$.

41 Pelz: $i . m$.

42 Lásd Németországot az OECD fejlesztési együttmüködési jelentéseiben 2009-ig: Development Co-operation Report, [online], 2009-2018, Forrás: oecd-library.org [2019. 09. 23.]

43 Deutschland und China: bilaterale Beziehungen, [online], 2019. 03. 21. Forrás: auswaertiges-amt.de [2019. 09. 23.]

44 Németország jelenlegi fejlesztési minisztere. Gerd Müller e tisztséget már a 2013-2017 között hivatalban lévő harmadik Merkel-kormányban is betöltötte.

45 Herr Müller, warum zahlt Deutschland Entwicklungshilfe für China? [online], 2019. 06. 14. Forrás: augsburger-allgemeine.de [2019. 09. 21.]

46 China, [online], Forrás: bmz.de [2019. 09. 21.]

47 Deutschland und China: bilaterale Beziehungen: $i . m$.

48 Herr Müller, warum zahlt Deutschland Entwicklungshilfe für China? i. m.

49 Deutschland und Indien: bilaterale Beziehungen, [online], 2019. 03. 21. Forrás: auswaertiges-amt.de [2019. 09. 23.] 
energiaforrások kiépítését, a városfejlesztést, a klímavédelmet vagy például vízgyüjtő területek rehabilitációját, továbbá az éhínség visszaszorítását, illetve a középosztály felemelkedésének támogatását például szakképzésfejlesztés révén. ${ }^{50}$ Indonézia Indiához hasonlóan szintén globális fejlesztési partner, egyre erősödő regionális nagyhatalom, a G20-országok egyike, így fontos szerepet tölt be a globális fejlesztési kérdések megoldásában, elsősorban az esőerdők védelmében. ${ }^{51}$

A 2015-ös migrációs válság óta a német fejlesztéspolitika határozottan a migrációs és biztonságpolitikai problémák felé fordult. Ennek megnyilvánulása, hogy 2015-től Törökország és különösen Szíria felkerültek a legfőbb német ODA-részesülök közé. Szíria számára 2016-2017-ben Németország volt a második legtöbb hivatalos fejlesztési támogatást nyújtó donor 852 millió dollár értékben. ${ }^{52}$ A támogatás tekintélyes része humanitárius segély volt. A BMZ támogatásai hozzájárulnak többek között szíriai gyermekek iskoláztatásához Libanonban, továbbá elősegítették az ivóvízhez és a különböző egészségügyi szolgáltatásokhoz való hozzáférés lehetőségét. ${ }^{53}$ Németország 2016-2017-ben Törökország számára a második legfontosabb támogató volt az Európai Unió intézményei után 510 millió dollárral. ${ }^{54}$ Törökország egyértelmúen kulcsszerepet játszik a menekültválság kezelésében, a német támogatások tekintélyes része az itt regisztrált közel 3,6 millió szíriai, illetve 350 ezer afgán, iraki és iráni menekült humanitárius segélyezésére és oktatására irányul. ${ }^{55}$

Afganisztán már több mint 10 éve hagyományosan a német fejlesztéspolitika célországa, Németország Afganisztán számára a második legtöbb hivatalos támogatást nyújtó partner, emellett az országban jelenleg 1300 Bundeswehr katona állomásozik a NATO Eltökélt Támogatás Missziójának (Resolute Support Mission) keretében 2020 márciusáig szóló mandátummal. ${ }^{56}$ Afganisztánban a BMZ többek között hozzájárul a jogállami struktúrák és a közigazgatás kiépítéséhez, a korrupció elleni harchoz, a mezőgazdasági öntözés helyreállításához, a közösségi infrastruktúrák kiépítéséhez, a szakképzéshez és tanácsadás révén segíti a civil szervezeteket. A BMZ ugyanakkor elvárja, hogy az afgán kormány is lépéseket tegyen a jó kormányzás, a korrupció elleni harc és a nők egyenjogúsága terén. ${ }^{57}$

Marokkó esetében a biztonságpolitikai és a gazdasági szempontok egyaránt érvényesülnek. Németország Marokkó hetedik legfontosabb kereskedelmi partnere, illetve elsőszámú donorja. ${ }^{58}$ Legutóbb, 2018 októberében Gerd Müller és a marokkói pénzügyminiszter német-marokkói reformpartnerségről tárgyalt. Ezenfelül Marokkó részt vesz a G20-országok „Compact with Africa” magánbefektetéseket ösztönző kezdeményezésében. A fejlesztési együttmüködés a megújuló energiaforrásokra, a vízellátásra és a fenntartható gazdaságfejlődésre összpontosul, így a BMZ támogatja például egy naperőmü

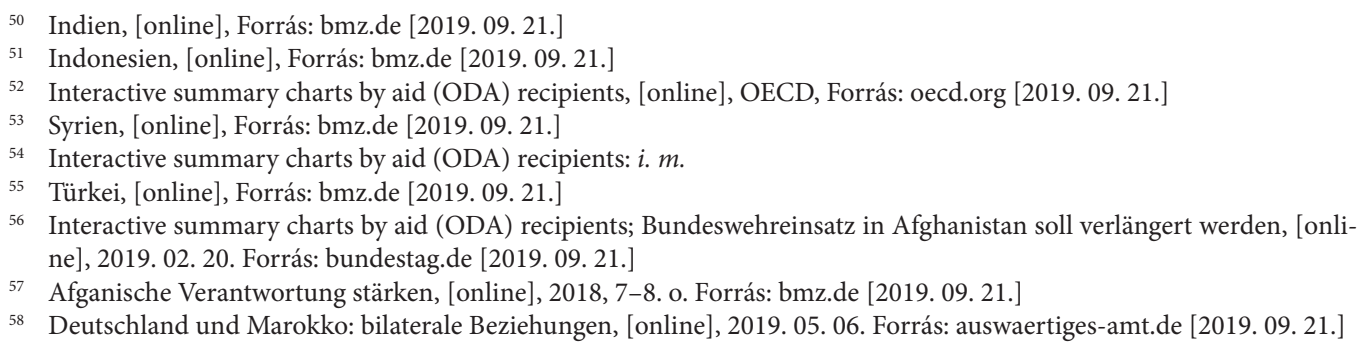

58 Deutschland und Marokko: bilaterale Beziehungen, [online], 2019. 05. 06. Forrás: auswaertiges-amt.de [2019. 09. 21.] 
létrehozását Ouarzazateban és Mideltben. Marokkót mint származási és tranzitországot a BMZ az Európából visszatérők reintegrációjában is támogatja. ${ }^{59}$

Az országpreferenciákat ugyanakkor több kritika is érte. A már említett Welthungerhilfe és a Terre des Hommes civil szervezetek idei jelentése szerint a fejlesztéspolitikának nem lenne szabad összefonódnia a migrációs és biztonságpolitikával, helyette a szegénység és az éhezés csökkentésére kellene fókuszálnia, ezzel szemben a legszegényebb országokba irányuló ODA évek óta stagnál. Mathias Mogge, a Welthungerhilfe fötitkára szerint a szövetségi kormány megfeledkezik azon országokról, ahol bár nincsen konfliktus, de törékenyek. Ilyen országok például Libéria, Sierra Leone vagy Szudán, ahol nem olyan régen polgárháborúk voltak, viszont szükség lenne a konfliktus utáni stabilizációra. ${ }^{60}$

Ami a globális partnereket illeti, 2019 áprilisában Markus Frohnmaier AFD-képviselő kérdőre vonta a kormányt, hogy az nem indokolja meg, miért támogat gazdasági hatalmakat a német adófizetők pénzéből, mivel e feltörekvő országok (mint például India és Kína, amelyek komoly haderővel és nukleáris fegyverzettel is rendelkeznek) saját kezükbe tudják venni fejlödésüket. Az AFD követelte, hogy a kormány ennek megfelelően hagyjon fel az Indonéziával, Pakisztánnal és Dél-Afrikával történő fejlesztési együttmüködéssel. A CDU/CSU szerint az AFD nem érti a fejlesztési együttműködés célját. A német gazdaságnak szüksége van a nemzetközi fejlesztési együttmüködésekre, továbbá a szegényebb országokban az olyan problémákat, mint a klímavédelem vagy a hulladékmentesítés csak globálisan lehet megoldani. Az FDP hasonlóan érvelt, miszerint a fejlesztési együttmüködés stratégiai fontosságú, gazdasági összetevővel bír, nem pedig pusztán segélyadományokat jelent. ${ }^{61}$

Jorge Moreira da Silva az OECD fejlesztési együttműködési igazgatójának 2018-as időközi értékelése is felhívja arra a figyelmet, hogy Németországnak el kell döntenie, mely fejlesztéspolitikai irányt kívánja követni: a klímaváltozás elleni harcot, az Addis Agendát ${ }^{62}$ vagy a menekültek számára nyújtott humanitárius segítségnyújtást. Amennyiben Németország tartja magát a szegénység csökkentéséhez, erősebben kell fókuszálnia a legkevésbé fejlett országoknak nyújtott ODA növelésére. ${ }^{63}$

Az eltérő fejlesztéspolitikai irányok (környezetvédelem, biztonságpolitika, külgazdaság) visszavezethetők a fentebb már említett több fejlesztéspolitikai szereplőre, az ebből fakadó eltérő érdekekre, amelyek eredményeképp a német fejlesztéspolitikát a koherencia hiánya jellemzi. Láthattuk, hogy a német fejlesztéspolitika diverzifikálódott, ez visszatükröződik abban, hogy a német hivatalos fejlesztési támogatásoknak csak kevesebb mint felét adja a BMZ. Az említett OECD-értékelés szerint a számos szereplö miatt Németország szá-

59 Marokko, [online], Forrás: bmz.de [2019. 09. 21.]

60 Alexandra ENDREs: „Wir reparieren die Folgen unserer Waffenexporte” [online], 2019. 04. 04. Forrás: zeit.de [2019. 09. 21.]

${ }^{61}$ Kontroverse Debatte über Entwicklunsförderung für Schwellenländer, [online], 2019. 04. 03. Forrás: bundestag.de [2019. 09. 21.]

62 A 2015. évi III. Fejlesztési Finanszírozási Konferencia Addis Ababában elindította az úgynevezett Addis Agendát, amely egyfajta globális keretrendszerként kívánja a pénzügyi forrásokat és politikákat összehangolni a gazdasági, társadalmi és környezetvédelmi prioritásokkal. Az Agenda politikai cselekvéseket és közel 100 konkrét lépést fogalmaz meg a pénzügyre, a technológiára, innovációra, kereskedelemre és az adósságokra vonatkozóan a fenntartható fejlödés érdekében. Lásd: Addis Ababa Action Agenda of the Third international Conference on Financing for Development, [online], Forrás: un.org [2019. 09. 22.]

63 Germany Mid-term Review, 7 November 2018, Berlin: i. m. 2. 
mára évek óta kihívást jelent egy összetartó, összkormányzati fejlesztéspolitikai program kialakítása. Az OECD javasolja, hogy a BMZ-nek meg kellene osztania a partnerországokra vonatkozó stratégiáit a többi kulcsszereplővel is, valamint jobban törekednie kellene a munkamegosztásra a többi fejlesztési partnerrel, például az Európai Unióval. ${ }^{64}$ Ehhez hasonlóan a német fejlesztéspolitika hibáiról árulkodik a hivatalos fejlesztési támogatások hatékonyságát mérő QuODA-Index ${ }^{65}$ is, amely a német fejlesztéspolitikát a 27 mért országból a 26. legrosszabb helyre sorolta be „partnerek tehermentesítése” kategóriában, mivel a fejlesztési együttmüködésben számos kormányzati szerv vesz részt, a programok részben lefedik egymást, így a segélyprogramokra töredezettség jellemző, ami összességében csökkenti a fejlesztési együttmüködés hatékonyságát. ${ }^{66}$

\section{Következtetés: a változó fejlesztéspolitika}

Kétségtelen, hogy az együttmüködések tartalmukat tekintve meghaladják a klasszikus fejlesztéspolitikát. E tendencia lehetséges magyarázata, hogy a német fejlesztéspolitika alapvető változásokon ment át az elmúlt 5 évben. A 2014-ben lefolytatott külpolitikai felülvizsgálat (Review 2014) eredményeként megszületett „müncheni konszenzus”67 mint külpolitikai koncepció Németország nagyobb globális felelősségvállalását helyezte a középpontba, Berlin kül- és biztonságpolitikai felfogása tehát változni látszik. Bár a fejlesztéspolitika már a 2000-es évektől a biztonságpolitika részévé vált, az újabb stratégiai dokumentumok, valamint a menekültválságban szerepet játszó célországok (Szíria, Törökország, részben Marokkó, illetve 2017-ben már Irak és Jordánia is) számára juttatott támogatások emelkedését tekintve megállapíthatjuk, hogy a „müncheni konszenzus” még erősebben a külés biztonságpolitikához és azon belül a válságkezeléshez kötötte azt.

A fejlesztéspolitika utóbbi években bekövetkezett felértékelődése jelentős mértékben a menekültválságnak köszönhető, ahogy ezt a hivatalos fejlesztési támogatások rekordszintü növekedése is bizonyítja. A menekülést kiváltó okok kezelése (Fluchtursachenbekämpfung) mint fejlesztési koncepció Németországban már az 1980-as évek óta vitatott kérdés, amely 2015 után került elötérbe a politikai diskurzusban, 2017-től igen erős Afrikaközpontúsággal, így indult meg több fejlesztési program, mint az afrikai Marshall-terv vagy Franciaország, Németország és az Európai Unió közös „Száhel Szövetség” ${ }^{8}$ kezdeményezése. Érdemes megjegyezni azonban, hogy a „Fluchtursachenbekämpfung” - ahogy erre már több migrációkutatás is rámutatott - kontraproduktív eszköz lehet, mivel ahogy egy

64 Uo. 3.

65 A QuODA-Indexet a Brookings Institution és a Center for Global Development fejlesztette ki a hivatalos fejlesztési támogatások hatékonyságának mérésére.

66 QuODA 2018 Data, [online], Forrás: cgdev.org [2019. 09. 23.]

67 A „müncheni konszenzusról” lásd bővebben: Csıкi Varga Tamás - ETL Alex: A „müncheni konszenzus” és Németország stratégiai jövőképe, [online], Stratégiai Védelmi Kutatóintézet Elemzések, 2019/19, 2019. 09. 19. Forrás: svkk. uni-nke.hu [2019. 09. 23.]

68 A Száhel Szövetséget Franciaország, Németország és az Európai Unió 2017 júliusában indította az Afrikai Fejlesztési Bankkal és az ENSZ Fejlesztési Programjával együttműködve, annak érdekében, hogy növeljék a Száhel-övezet stabilitását és fejlődését közel 730 projekt finanszírozásával a mezőgazdaság, élelmiszerbiztonság, kormányzás, oktatás, energia és klímavédelem terén. Lásd: alliance-sahel.org [2019. 09. 23.] 
országban nőnek a bérek, javulnak a társadalmi, gazdasági és politikai feltételek, úgy egyre több ember kíván elvándorolni. ${ }^{69}$

A válságkezelés mellett fontos leszögezni, hogy az olyan klasszikus törekvések, mint például a szegénység elleni küzdelem, amely az 1998-2009 közötti fejlesztési miniszter, Heidemarie Wieczorek-Zeul alatt meghatározó volt, újra előtérbe kerültek. ${ }^{70}$

Összességében tehát a fejlesztéspolitika funkciója fokozatosan kibővült, és a hidegháború korabeli klasszikus fejlesztési együttmüködésből mára komplexebb gazdasági és biztonsági érdekeket szolgáló eszköz lett. Ebből kifolyólag a kritikák egy része, amely a klasszikus fejlesztési együttműködést szorgalmazza, megfeledkezik arról, hogy afelett „eljárt az ido”, a globális kihívások kezeléséhez és a válságmegelőzéshez valóban szélesebb és komplexebb fejlesztéspolitikai megközelítésre van szükség. Más kérdés, hogy ezen „új” fejlesztéspolitikai irány egyrészt nem alkot egységes struktúrát, a különböző fejlesztéspolitikai irányok keverednek egymással, másrészt erősen részrehajló („menekültválság-központúság”). A különféle és saját nemzeti érdekeket követő fejlesztéspolitikai projektek és kezdeményezések azzal a kockázattal fenyegetnek, hogy a fejlesztéspolitika elsekélyesedik, elveszíti eredeti célkitüzését. Ellenpéldaként szolgálhat az Egyesült Államok, amely a fejlesztéspolitikát 9/11 óta egyértelműen a biztonságpolitikának rendeli alá. ${ }^{71} \mathrm{~A}$ német politikai vezetésnek tiszta irányokat kellene megszabnia arra vonatkozóan, hogy mely fejlesztéspolitikai célokat tartja prioritásnak (a klímaváltozás elleni fellépést, a szegénység felszámolását vagy a menekülést kiváltó okok kezelését és a válságkezelést, esetleg Afrika felzárkóztatását) és e szerint kellene a célországokat is megválasztania. Ha Németország a „müncheni konszenzusnak” megfelelően valóban hitelesen, felelősséget kíván vállalni a nemzetközi rendszer stabilizálása érdekében, ahogy ezt Frank Walter Steinmeier egykori külügyminiszter hangoztatta 2015-ben, úgy koordináltabban és megfontoltabban kell kül- és biztonságpolitikáját alkalmaznia, beleértve a fejlesztéspolitikát is. ${ }^{72}$ A következő években meghatározó kérdés lesz a 2014 utáni német kül- és biztonságpolitikát illetően, hogy az új fejlesztéspolitikai irány nem pusztán egy retorikai ígéretnek bizonyul-e, amely csak a menekült- és migrációs válság tüneteit kezelő eszközként szolgál, hanem hosszú távon nyújt megoldást a globális kihívásokra.

\section{FELHASZNÁLT IRODALOM}

Addis Ababa Action Agenda of the Third international Conference on Financing for Development, [online], Forrás: un.org [2019. 09. 22.]

Afganische Verantwortung stärken, [online], 2018. Forrás: bmz.de [2019. 09. 21.]

Afrika und Europa - Neue Partnerschaft für Entwicklung, Frieden und Zukunft, [online], 2017. Forrás: bmz. de [2019. 09. 22.]

69 Benjamin Schraven: Fluchtursachenbekämpfung: Die deutsche Debatte, [online], 2019, 30-32. o. Forrás: ifri.org [2019. 09. 23.]

70 Hermann-Hillebrecht-Lehmann: i. m. 193.

71 Silke Weinlich - Dennis Michels: Entwicklungspolitik als Antwort auf Sicherheitsprobleme?, [online], Informationen zur politischen Bildung Nr. 326/2015, Forrás: bpb.de [2019. 09. 23]

72 „Die Welt ist aus den Fugen geraten” - Rede von Außenminister Frank-Walter Steinmeier beim Deutschen Evangelischen Kirchentag, Stuttgart, [online], 2015. 06. 07. Forrás: auswaertiges-amt.de [2019. 09. 24.] 
Annual Accounts of the European Development Fund 2018, [online], 2019. 06. 26. Forrás: europarl.europa.eu [2019. 09. 21.]

Auswahl der Kooperationsländer, [online], Forrás: bmz.de [2019. 09. 21.]

Bericht: Deutsche Entwicklungspolitik missachtet die ärmsten, [online], 2019. 04. 04. Forrás: dw.com [2019. 09. 21.]

BRAND, Alexander: Sicherheit über alles? Die schleichende Versicherheitlichung deutscher Entwicklungspolitik, [online], Peripherie: Zeitschrift für Politik und Ökonomie in der Dritten Welt, 31 évf. 2011/122-123, 209-235. o. Forrás: zeitschrift-peripherie.de [2019. 09. 21.] DOI: https://doi.org/10.3224/ peripherie.v31i122-123.24040

China, [online], Forrás: bmz.de [2019. 09. 21.]

Commitment to Development Index 2018 Germany, [online], Forrás: cgdev.org [2019. 09. 20.]

Country programmable aid (CPA), [online] Forrás: oecd.org [2019. 09. 11.]

Csiki VARga Tamás - ETL Alex: A „müncheni konszenzus” és Németország stratégiai jövőképe, [online], Stratégiai Védelmi Kutatóintézet Elemzések, 2019/19, 2019. szeptember 19. Forrás: svkk.uni-nke.hu [2019. 09. 23.]

„Die Welt ist aus den Fugen geraten” - Rede von Außenminister Frank-Walter Steinmeier beim Deutschen Evangelischen Kirchentag, Stuttgart, [online], 2015. 06. 07. Forrás: auswaertiges-amt.de [2019. 09. 24.]

Deutsche Nachhaltigkeitsstrategie. Neuauflage 2016, [online], 2016, Forrás: bundesregierung.de [2019. 09. 09.]

Entwicklungspolitik ist Zukunftspolitik. Ressortbericht zur Umsetzung der Deutschen Nachhaltigkeitsstrategie und der SDGs, [online], 2018, Forrás: bmz.de [2019. 09. 09.]

Deutschland und China: bilaterale Beziehungen, [online], 2019. 03. 21. Forrás: auswaertiges-amt.de [2019. 09. 23.]

Deutschland und Indien: bilaterale Beziehungen, [online], 2019. 03. 21. Forrás: auswaertiges-amt.de [2019. 09. 23.]

Deutschland und Marokko: bilaterale Beziehungen, [online], 2019. 05. 06. Forrás: auswaertiges-amt.de [2019. 09. 21.]

Development co-operation profiles 2019 - Germany, [online], Forrás: oecd-library.org [2019. 09. 09.]

Development Co-operation Profiles 2019 - official providers, [online], Forrás: oecd.org [2019. 09. 11.]

Development Co-operation Report, [online], 2009-2018, Forrás: oecd-library.org [2019. 09. 23.]

Durchführungsorganisationen, [online], Forrás: bmz.de [2019. 09. 11.]

ENDRES, Alexandra: „Wir reparieren die Folgen unserer Waffenexporte”, [online], 2019. 04. 04. Forrás: zeit.de [2019. 09. 21.]

Entwicklungspolitik 2030. Neue Herausforderungen - neue Antworten, [online], 2018. Forrás: bmz.de [2019. 09. 11.]

Entwicklungspolitik als Zukunfts- und Friedenspolitik. 15. Entwicklungspolitischer Bericht der Bundesregierung, [online], 2017. Forrás: bmz.de [2019. 09. 09.]

Entwicklungspolitische Zusammenarbeit mit Globalen Entwicklungspartnern, [online], 2015, Forrás: bmz.de [2019. 09. 23.]

Entwicklungszusammenarbeit, [online], Forrás: bmz.de [2019. 09. 11.]

Geber im Vergleich 2018, [online], Forrás: bmz.de [2019. 09. 09.]

Germany Mid-term Review, 7 November 2018, Berlin, [online], 2018. 12. 14. Forrás: oecd.org [2019. 09. 10.]

Haushalt, [online], Forrás: bmz.de [2019. 09. 09.]

Hermann, Hannes - Hillebrecht, Moritz - Lehmann, Tobias: Vom solidarischen Kollektiv, unternehmerischen Entwicklungssubjekten und der Einen Welt. In: Deutsche Außenpolitik. Arenen, Diskurse und Grundlegende Handlungsregeln. Ulrich Roos Hrsg., Springer VS, 2017, s. 171-215. DOI: https://doi. org/10.1007/978-3-658-15370-0_6

Herr Müller, warum zahlt Deutschland Entwicklungshilfe für China?, [online], 2019. 06. 14. Forrás: augsburger-allgemeine.de [2019.09. 21.]

How does the World Bank classify countries?, [online], Forrás: datahelpdesk.worldbank.org [2019. 09. 09.]

Indien, [online], Forrás: bmz.de [2019. 09. 21.]

Indonesien, [online], Forrás: bmz.de [2019. 09. 21.] 
In-donor refugee costs in ODA, [online], Forrás: oecd.org [2019. 09. 23.]

Interactive summary charts by aid (ODA) recipients, [online], OECD, Forrás: oecd.org [2019. 09. 21.]

Interactive summary charts by aid (ODA) recipients; Bundeswehreinsatz in Afghanistan soll verlängert werden, [online], 2019. 02. 20. Forrás: bundestag.de [2019. 09. 21.]

Kontroverse Debatte über Entwicklunsförderung für Schwellenländer, [online], 2019. 04. 03. Forrás: bundestag.de [2019. 09.21.]

Krisen verhindern, Konflikte bewältigen, Frieden fördern. Leitlinien der Bundesregierung, [online], 2017. Forrás: auswaertiges-amt.de [2019. 09. 09.]

Marokko, [online], Forrás: bmz.de [2019. 09. 21.]

Nuscheler, Franz: Entwicklungspolitik. In: Handbuch zur deutschen Außenpolitik. ScHмidt Siegmar - HellmanN, Gunther - Wolf, Reinhard Hrsg., VS Verlag für Sozialwissenschaften, 2007, s. 675-676.

PELZ, Daniel: Hilfsorganisationen stellen deutscher Afrikapolitik schlechtes Zeugnis aus, [online], 2019. 04. 04. Forrás: dw.com [2019. 09. 09.]

QuODA 2018 Data, [online], Forrás: cgdev.org [2019. 09. 23.]

SCHRAVEN, Benjamin: Fluchtursachenbekämpfung: Die deutsche Debatte, [online], 2019. Forrás: ifri.org [2019. 09. 23.]

Scope and Structure of German Official Development Assistance: Trends and Implications for the BMZ and Other Ministeries, [online], Deutsches Institut für Entwicklungspolitik, Briefing Paper 16/2018, Forrás: die-gdi.de [2019. 09. 09.] DOI: https://doi.org/10.23661/bp16.2018

Südhoff, Ralf - Hövelmann, Sonja: Where does German humanitarian assistance stand?, [online], 2019. 03. 08. Forrás: chaberlin.org [2019. 09. 20.]

Syrien, [online], Forrás: bmz.de [2019. 09. 21.]

The Commitment to Development Index: 2018 Edition. Methodological Overview Paper, [online], 2018. Forrás: cgdev.org [2019. 09. 12.]

Titz, Christoph - Feck, Maria: Der Wassermann, [online], 2017. 07. 26. Forrás: spiegel.de [2019. 09. 23.]

Türkei, [online], Forrás: bmz.de [2019. 09. 21.]

WeInlich, Silke - Michels, Dennis: Entwicklungspolitik als Antwort auf Sicherheitsprobleme?, [online], Informationen zur politischen Bildung Nr. 326/2015. Forrás: bpb.de [2019. 09. 23]

Weißbuch 2016 zur Sicherheitspolitik und zur Zukunft der Bundeswehr, [online], 2016, Forrás: bundesregierung.de [2019. 09. 09.]

World Bank Country and Lending Groups, [online], Forrás: databank.worldbank.org [2019. 09. 09.] 